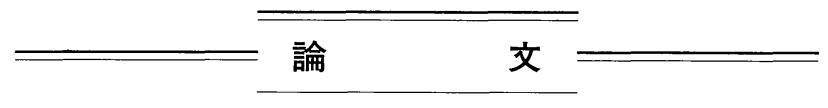

農業気象(J. Agr. Met.) 43 (2): 105-111, 1987

\title{
Boundary-Layer Transfer Coefficient for a Fluttering Leaf \\ II. Model Experiments to Evaluate Effects of Leaf Inclination and Fluttering on Transfer Coefficient
}

\author{
Tetsuya Haseba, Daijiro Ito and Atsushi Nishikawa \\ $\left(\begin{array}{c}\text { Division of Agricultural Meteorology, } \\ \text { College of Agriculture, Ehime University } \\ \text { Matsuyama 790, Japan }\end{array}\right)$
}

\begin{abstract}
Laboratory experiments were performed to evaluate boundary-layer transfer coefficients for fluttering plant leaves in winds at various mean attack angles to the fluctuating flow. In these experiments, water vapor transfer was investigated by using rectangular flat leaf models of various dimensions fluttering resonantly with the fluctuation of artificial air streams with similar intensities of turbulence to natural flows within plant canopies. Most of the water-vapor transfer coefficients evaluated for upstream- and downstream-facing surfaces were larger than those estimated from the laminar boundary-layer theory. In a range of Reynolds numbers below a critical value between $3 \times 10^{3}$ and $3 \times 10^{4}$, the transfer coefficients were apparently proportional to the square root of the mean flow speed. Under this Reynolds number range, the ratio of the experimental transfer coefficient to that estimated from the theory was expressed as a function of the model dimensions at each fluttering number and at each attack angle.

The enhancement of the transfer coefficients for fluttering leaf models at various attack angles is discussed in conjunction with fluid turbulence, large eddies, the pressure distribution over the model surface and the model-fluttering.
\end{abstract}

\section{Introduction}

Under field conditions, plant leaves are usually fluttering in fluctuating winds. Because the fluttering of a leaf is caused by bending and torsion in the petiole, leaf and branch, the leaf shows various patterns of the fluttering within a canopy (Haseba, 1975). However, the plant leaf shows frequently a lateral and periodic vibration lasting for several seconds at a time, when the fluctuation frequency of the air flow in the wind is nearly equal to the characteristic frequency of the leaf (Haseba et al., 1986).

The leaf-fluttering affects the energy and gas transfers across the leaf boundary-layer (Schuepp, 1972; Haseba, 1975), and has some effects on the

Read at the Annual Meeting on 30 May, 1985.

Received 20 November, 1986. plant growth. The transfer problems for a leaf fluttering in a turbulent air flow have been studied by Raschke (1956), Parkhurst et al. (1968), Parlange et al. (1971), Parlange and Waggoner (1972), Pearman et al. (1972), Schuepp (1972), Parkhurst and Pearman (1974), Haзeba (1975), Yabuki and Harazono (1978), and Harazono and Yabuki (1979). However, the effects of the inclination of the leaf to the main air flow and the fluttering number on the transfer have not been dealt with. Haseba et al. (1986) presented experimental equations of the transfer coefficient for flat leaf models fluttering in fluctuating parallel flows with similar intensities of turbulence to natural winds. The equations expressing the ratios of the experimental transfer coefficients to those estimated from the theory were presented as a function of leaf dimensions and mean wind speed. 
There remains unrevealed actualities such as relationships among the transfer coefficient, the mean attack angle to the flow and the fluttering number. The results of laboratory experiments concerning the above problems are presented here, and some experimental equations of the transfer coefficients for fluttering leaf-models are presented and discussed.

\section{Methods}

The wind tunnel, leaf models, and their vibrating equipment and the method to evaluate the boundary-layer transfer coefficient for water-vapor were the same as those described in previous papers (Haseba, 1975; Haseba et al., 1986). Artificial air flows had the patterns of speed fluctuation and intensities of turbulence similar to those of natural winds within plant canopies. When the fluctuation frequency of the flow speed was set near on the characteristic frequency of the model, a resonant vibration of the model was observed. The smooth surfaces of the rectangular plates as leaf-models were wetted as a source of evaporation. The amount of evaporation from the upper surface of the model with the swinging leading edge was measured (Haseba, 1975; Haseba et al., 1986). The models were 1 to $32 \mathrm{~cm}$ both in length (l) and width $(s)$. Thirty-six kinds of models were used for the experiment.

The measurements for evaluating the transfer coefficients included the flow speed and intensity of turbulence, dry and wet bulb temperatures and evaporative surface temperature. The experiments were made under a stationary condition of an air temperature between 18 and $22^{\circ} \mathrm{C}$ and a relative humidity between 30 and $60 \%$. The mean flow speed ranged from 0.4 to $5 \mathrm{~m} \mathrm{sec}^{-1}$ and the fluttering numbers of the resonantly vibrating model were $0.25,0.5,1,2,3$ and $4 \mathrm{~Hz}$. The mean attack angle $(\phi)$ was set at values of $0^{\circ}$, $\pm 30^{\circ}$ and $\pm 60^{\circ}$ in the middle position of the fluttering model. At a negative attack angle the evaporative surface was against the flow and at a positive angle, the surface faced leeward. The angles of vibration varied from $20^{\circ}$ to $90^{\circ}$ for fluttering numbers $(f)$ from 0.25 to $2 \mathrm{~Hz}$ and from $5^{\circ}$ to $10^{\circ}$ at 3 and $4 \mathrm{~Hz}$, respectively. The amplitudes varied from 1 to $50 \mathrm{~cm}$ at low $f$ and from 1 to $5 \mathrm{~cm}$ at high $f$, respectively: they were naturally dependent on $f, \phi, l$ and $s$.

As a fiducial coefficient, the theoretical forcedconvection transfer coefficient $\left(D_{T H}, \mathrm{~cm} \mathrm{sec}^{-1}\right)$, was calculated for the laminar boundary-layer on an isothermal flat plate in a parallel air flow (Haseba and Ito, 1980).

When the transfer coefficient obtained in the experiments was nearly proportional to the square root of the mean flow speed, experimental equations were determined by the least squares method in the following form,

$$
D=a u^{0.5},
$$

where $D$ is an experimental transfer coefficient in $\mathrm{cm} \mathrm{sec}^{-1}, a$ is an empirical coefficient and $u$ is the mean flow speed in $\mathrm{cm} \mathrm{sec}^{-1}$. Further, a ratio was defined by

$$
\alpha=D / D_{T H} .
$$

The ratio $(\alpha)$ indicates the enhancement of the transfer coefficient for the fluttering leaf model obtained from the experiment as compared with the theoretical one.

\section{Results}

The water-vapor transfer coefficients for rectangular leaf models fluttering resonantly with the fluctuation of the air flow are illustrated in Fig. 1 as a function of the mean flow speed.

In Fig. 1, the bold lines express the regression relationships for the experimental coefficients obtained by the least squares method. The thin lines indicate the theoretical relations and the broken lines represent the empirical relations between the transfer coefficient and the flow speed for the stationary equal-size rectangular leaf models at an attack angle of $-60^{\circ}$ as obtained after Haseba and Ito (1984).

For a model of $1 \mathrm{~cm}$ in width $(s)$ and $32 \mathrm{~cm}$ in length $(l)$ in Fig. $1 \mathrm{~A}$ and B, the transfer coefficient shows a critical wind speed where the slopes of the lines make a discrete change. It suggests the transition from the laminar boundary-layer to the turbulent one. The critical Reynolds number $(R e, c r)$ obtained from the experimens was about $3 \times 10^{4}$. The values of $R e, c r$ where the transitions occurred were scattered with the aspect ratio $(l / s)$ of a model, the fluttering number and the attack angle; that is, they were about $3 \times 10^{3}$ for the 


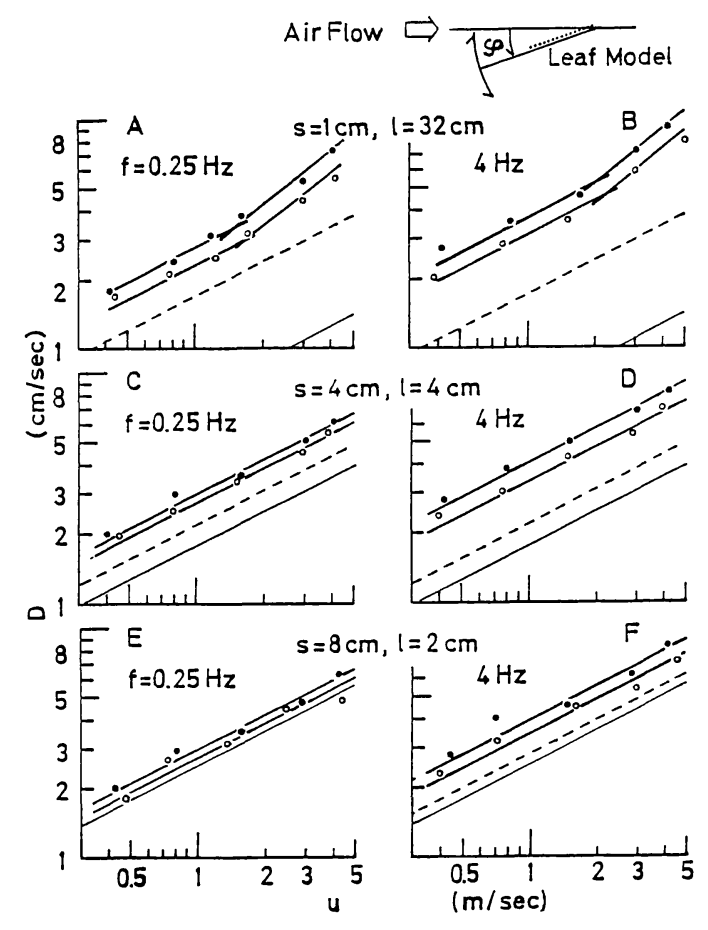

Fig. 1. Water-vapor transfer coefficient $(D)$ for fluttering leaf model at 0.25 and $4 \mathrm{~Hz}$ in fluttering number $(f)$ as a function of mean flow speed $(u)$. Points and circles indicate coefficients for models at $-60^{\circ}$ and $60^{\circ}$ attack angles $(\phi)$, respectively; and $s$ is model width and $l$ model length.

models 1 to $2 \mathrm{~cm}$ long, and ranged from $1 \times 10^{4}$ to $3 \times 10^{4}$ for those 4 to $32 \mathrm{~cm}$ long.

Most of the experimental transfer coefficients were larger than the theoretical ones. The difference between the experimental coefficients and the theoretical ones varied with the model dimension, the attack angle and the fluttering number. For broad leaf models fluttering at low frequencies, the experimental transfer coefficients were approx. imately equal to the theoretical ones. For a model whose length was larger than its width, the enhancement of transfer became larger in comparison with models of different shapes. These results are similar to the features of the transfer coefficient for a stationary leaf model in a laminar air flow (Haseba and Ito, 1984) and that for a fluttering model at zero angle of attack (Haseba et al., 1986).

In Fig. 2 are presented the enhancement ratios $(\alpha)$ against the mean attack angles $(\phi)$. For the

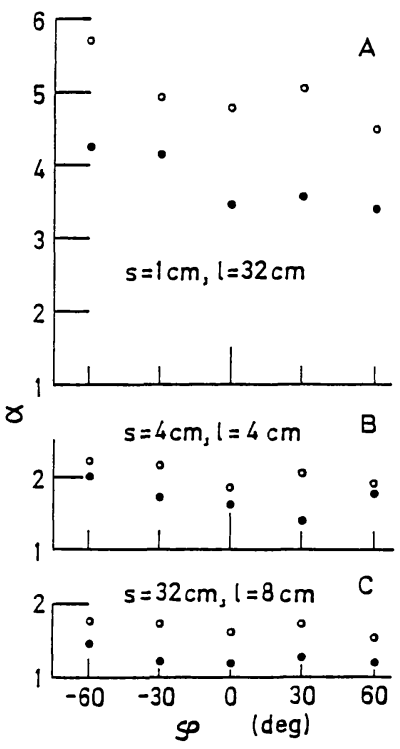

Fig. 2. Enhancement ratio $(\alpha)$ of experimental transfer coefficient to theoretical one vs. attack angle $(\phi)$. Points and circles indicate ratios for models at 0.25 and $4 \mathrm{~Hz}$ fluttering numbers, respectively.

evaporative surfaces facing upstream, the ratios increased with an increase in absolute value of the negative mean attack angle. On the other hand, for those facing leeward, the ratio showed little change with the angle.

Fig. 3 shows the fluttering number $(f)$ dependence of $\alpha$. The ratio $(\alpha)$ increased with increasing $f$. At zero frequency, the ratios estimated by extrapolation in Fig. 3 were nearly equal to those for the stationary equal-size models at the same attack angle in a fluctuating flow (Haseba and Ito, 1984).

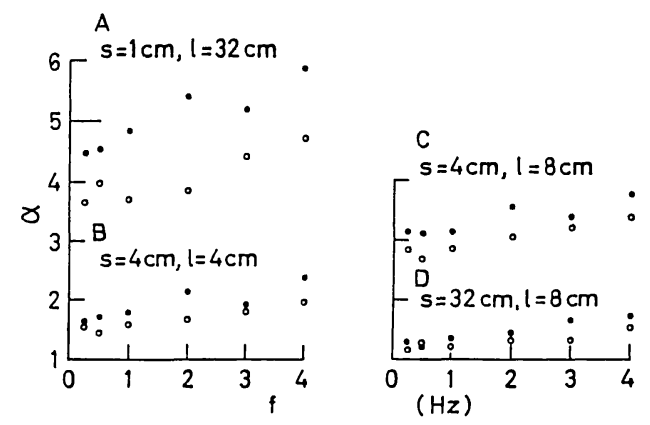

Fig. 3. Enhancement ratio $(\alpha)$ of transfer coefficient vs. fluttering number $(f)$. Points and circles indicate ratios for models at $-60^{\circ}$ and $60^{\circ}$ attack angles, respectively. 


\section{Discussion}

In Fig. 4 are illustrated the ratios of the transfer coefficient $\left(D, \mathrm{~cm} \mathrm{sec}^{-1}\right)$ for a resonantly fluttering leaf model to that $\left(D_{s}\right)$ for a stationary one in the fluctuating flow against the attack angle $(\phi)$. The transfer coefficient ratios $\left(D / D_{s}\right)$ were little correlated with the attack angle. This showed that the fluttering increased the transfer coefficient by only 5 to $10 \%$ as compared with the coefficient for the stationary models obtained by Haseba (1975). These results are in quantitative agreement with those by Raschke (1956) and Parkhurst et al. (1968). For leaf models with various aspect ratios $(l / s)$ from 0.03 to 32 , investigated in this experiment, it was confirmed that the effect of the model-fluttering was small on the enhancement of the boundary-layer transfer coefficient in the turbulent air flow.
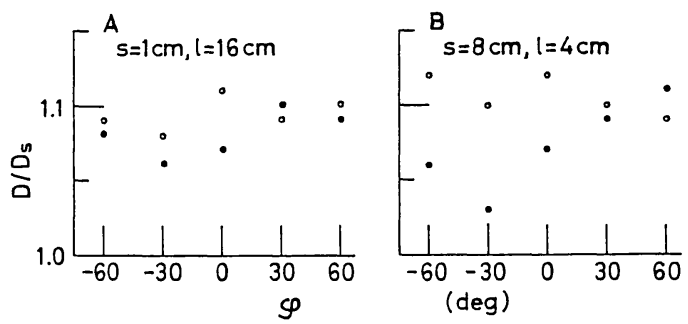

Fig. 4. Effect of model-fluttering on transfer coefficient. $D$ and $D_{s}$ are transfer coefficients for fluttering and stationary leaf models in fluctuating air flow, respectively. Points and circles indicate ratios, $D / D_{s}$, for models at 0.25 and $4 \mathrm{~Hz}$ fluttering numbers, respectively.

Relationships between $\alpha$ and $l$ in the flow direction are illustrated in Fig. 5, where broken lines represent the regression relationships from the experimental equations in the previous paper (Haseba et al., 1986). The experimental results showed linear regressions between the logarithm of $\alpha$ and that of $l$ coordinates, except for a range of small $l$ with broad leaf models as shown in Fig. 5 E. The ratio increased with increasing model length. The negative attack angles disclosed larger ratios than their respective positive angles. Only a small difference between the ratios at a positive attack angle and at zero angle was observed. In a range of the model lengths shorter than $2 \mathrm{~cm}$ in

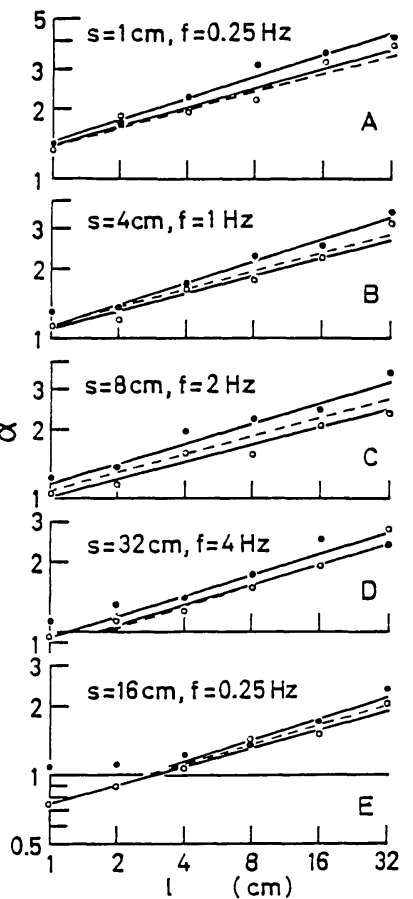

Fig. 5. Enhancement ratio $(\alpha)$ of transfer coefficient as a function of leaf model length $(l)$ for models of various widths $(s)$ and at fluttering numbers $(f)$. Points and circles indicate ratios for models at $-60^{\circ}$ and $60^{\circ}$ attack angles, respectively.

Fig. $5 \mathrm{E}$, it is noticed that the values of $\alpha$ for a broad leaf model at negative attack angles and at a low fluttering number of $0.25 \mathrm{~Hz}$ were distinctly larger than those predicted from the linear regression. These ratios were nearly equal to those for a stationary model inclined to a laminar air flow (Haseba and Ito, 1984). On the other hand, for models at positive attack angles $\log \alpha$ was linear against $\log l$ in the whole range of the model lengths examined in this experiment.

Relationships between $\alpha$ and $s$ are shown in Fig. 6. The ratios decreased with increasing $s$. Linear relationships between $\log \alpha$ and $\log s$ were revealed.

The results described above suggest that, below a critical Reynolds number where the transfer coefficient is proportional to the square root of the mean flow speed, an experimental equation among the enhancement ratio $(\alpha)$ and the model length $(l, \mathrm{~cm})$ and the width $(s, \mathrm{~cm})$ of a rectangular leaf model fluttering in a fluctuating air flow 


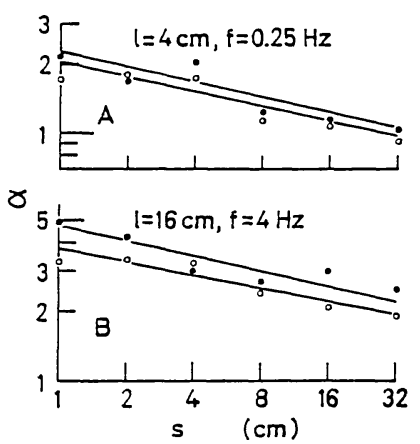

Fig. 6. Enhancement ratio $(\alpha)$ of transfer coefficient as a function of leaf model width $(s)$. Points and circles indicate ratios for models at $-60^{\circ}$ and $60^{\circ}$ attack angles, respectively.

is formulated as

$$
\alpha=A l^{x} s^{y} .
$$

Table 1 contains the values of empirical coefficient $(A)$, and the exponents $(x, y)$ in Eq. (3) for the leaf models of 1 to $32 \mathrm{~cm}$ both in length and width at different fluttering numbers and at selected mean attack angles. For the models at zero and negative attack angles, such equations are applicable in a range of model dimensions expressed by

$$
l \geqq B s^{2} .
$$

This originates from the condition that $\alpha \geqq 1$, because in a range of $\alpha$ below unity a linear regression between $\log \alpha$ and $\log l$ and/or $\log s$ was not observed. The values of $B$ and $z$ are given in Table 1. The coefficients of determination by these equations were from 0.75 to 0.95 .

For the models at negative attack angles, $A$ increased clearly and the absolute values of $x$ and $y$ increased slightly with increasing absolute value of $\phi$ at each fluttering number. On the other hand, for the models at zero and positive attack angles, small differences are observed respectively in $A, x$ and $y$.

In practical application for estimating $D$ from $D_{T H}$, a few equations representing $\alpha$ are desirable for every combination of $f$ and $\phi$. With all the models in this study it is difficult to find a significant relation between $x$ or $y$ and $f$. However, $A$ increased approximately linearly with increasing $f$. Then, $A$ is expressed as follows,

$$
A=a+b f,
$$

where $a$ and $b$ are numerical coefficients.

At each positive and zero attack angle, the following regression equations were obtained with mean values of the exponents $(x, y)$.

$$
\begin{aligned}
& \alpha=(1.35+0.081 f) l^{0.28} s^{-0.21}, \text { at } \phi=60^{\circ} ; \\
& \alpha=(1.33+0.089 f) l^{0.29} s^{-0.20}, \text { at } \phi=30^{\circ} ; \\
& \alpha=(1.35+0.076 f) l^{0.29} s^{-0.20}, \text { at } \phi=0^{\circ} .
\end{aligned}
$$

\begin{tabular}{|c|c|c|c|c|c|c|c|c|c|c|c|c|c|c|c|}
\hline$f(\mathrm{~Hz})$ & \multicolumn{5}{|c|}{0.25} & \multicolumn{5}{|c|}{0.5} & \multicolumn{5}{|c|}{1} \\
\hline$\phi$ (deg) & 60 & 30 & 0 & -30 & -60 & 60 & 30 & 0 & -30 & -60 & 60 & 30 & 0 & -30 & -60 \\
\hline A & 1.38 & 1.38 & 1.36 & 1.51 & 1.48 & 1.31 & 1.28 & 1.35 & 1.52 & 1.60 & 1.48 & 1.43 & 1.44 & 1.58 & 1.55 \\
\hline$x$ & 0.28 & 0.25 & 0.27 & 0.29 & 0.31 & 0.27 & 0.30 & 0.28 & 0.32 & 0.31 & 0.26 & 0.29 & 0.27 & 0.29 & 0.32 \\
\hline $\mathrm{y}$ & -0.21 & -0.19 & -0.20 & -0.23 & -0.22 & -0.20 & -0.23 & -0.21 & -0.26 & -0.27 & -0.22 & -0.21 & -0.19 & -0.20 & -0.23 \\
\hline B & --- & --- & 0.32 & 0.24 & 0.28 & --- & --- & 0.34 & 0.27 & 0.22 & --- & --- & 0.26 & 0.21 & 0.25 \\
\hline$z$ & --- & $-\cdots$ & 0.74 & 0.79 & 0.71 & --- & --- & 0.75 & 0.81 & 0.87 & --- & --- & 0.70 & 0.69 & 0.72 \\
\hline
\end{tabular}

\begin{tabular}{|c|c|c|c|c|c|c|c|c|c|c|c|c|c|c|c|}
\hline$f(\mathrm{~Hz})$ & \multicolumn{5}{|c|}{2} & \multicolumn{5}{|c|}{3} & \multicolumn{5}{|c|}{4} \\
\hline$\phi$ (deg) & 60 & 30 & 0 & -30 & -60 & 60 & 30 & 0 & -30 & -60 & 60 & 30 & 0 & -30 & -60 \\
\hline A & 1.60 & 1.58 & 1.61 & 1.82 & 1.90 & 1.58 & 1.57 & 1.54 & 1.68 & 1.60 & 1.65 & 1.66 & 1.64 & 1.85 & 2.01 \\
\hline$x$ & 0.26 & 0.29 & 0.27 & 0.31 & 0.30 & 0.29 & 0.28 & 0.31 & 0.32 & 0.34 & 0.30 & 0.32 & 0.31 & 0.30 & 0.31 \\
\hline$y$ & -0.22 & -0.20 & -0.20 & -0.25 & -0.24 & -0.19 & -0.18 & -0.20 & -0.21 & -0.22 & -0.19 & -0.19 & -0.20 & -0.20 & -0.22 \\
\hline B & - - & - - - & 0.17 & 0.15 & 0.12 & --- & --- & 0.25 & 0.20 & 0.25 & --- & --- & 0.20 & 0.13 & 0.11 \\
\hline$z$ & --- & --- & 0.74 & 0.81 & 0.80 & --- & --- & 0.65 & 0.66 & 0.65 & --- & --- & 0.65 & 0.67 & 0.71 \\
\hline
\end{tabular}

Table 1. Numerical coefficients and values of exponents in Eq. (3) representing relationship between enhancement ratio $(\alpha)$ of experimental transfer coefficient and dimensions of leaf model, and those in Eq. (4) representing dimension range under which Eq. (3) is applicable. 
These are applicable over the range of

$$
l \geqq 0.36 s^{0.69} \text {. }
$$

Because $A, x$ and $y$ are not so different respectively in the above equations, the following equation was obtained after a rearrangement,

$$
\alpha=(1.34+0.085 f) l^{0.28} s^{-0.20} .
$$

This is applicable over the range of

$$
l \geqq 0.35 s^{0.71} \text {. }
$$

Then, at each negative angle:

$$
\alpha=(1.51+0.086 f) l^{0.31} s^{-0.23} \text {, at } \phi=-30^{\circ} .
$$

This is applicable over the range of

$$
\begin{aligned}
& l \geqq 0.27 s^{0.74} . \\
& \alpha=(1.50+0.108 f) l^{0.32} s^{-0.23}, \text { at } \phi=-60^{\circ} .
\end{aligned}
$$

This is applicable over the range of

$$
l \geqq 0.28 s^{0.72} \text {. }
$$

The ratio $(\alpha)$ is dimensionless as shown in Eq. (2). But $(x+y)$ is not always zero: i.e. $\alpha$ is not only related with the aspect ratio of the model $(l / s)$. As pointed out by Raschke (1956), $D$ is a function of $s$ : later the dimension dependence of $D$ was discussed by Haseba and Ito (1980). Although, in this study, $A$ was expressed by a constant, it may be expressed as a function of model dimensions. But, unfortunately, any reasonable representation could not be found.

Several examples of the enhancement ratios $(\alpha)$ of the transfer coefficient are evaluated according to the above equations. The ratios for a leaf model $4 \mathrm{~cm}$ wide and $8 \mathrm{~cm}$ long fluttering in fluctuating flow at $2 \mathrm{~Hz}$ are 1.17, 1.13, 2.14, 2.45 and 2.54 at attack angles of $60^{\circ}, 30^{\circ}, 0^{\circ}$, $-30^{\circ}$ and $-60^{\circ}$, respectively. At the fluttering numbers of $0.25,0.5,1,2,3$ and $4 \mathrm{~Hz}$, the ratios for a model of the same dimension at $-60^{\circ}$ attack angle are 2.08, 2.10, 2.19, 2.54, 2.39 and 2.82, respectively. These values are larger by 50 to $100 \%$ than those for the stationary leaf models inclined at the same angles to a laminar air flow (Haseba and Ito, 1984). Further, the enhancement ratios for narrow fluttering leaf models are larger than those for broad fluttering ones.

When $\alpha=2.5$ for a leaf model $8 \mathrm{~cm}$ long, $D$ is estimated to be about $3.3 \mathrm{~cm} \mathrm{sec}^{-1}$ which is larger than a natural stomatal conductance. This indicates that the boundary-layer transfer coefficient for a fluttering leaf inclined to the wind does not obstruct the diffusion of water vapor in transpiration or carbon dioxide in photosynthesis.

Boundary-layer transfer coefficients are enhanced owing to the inclination of a plant leaf to the main air flow. Further, the intensities of turbulence from several tens to a hundred percent and the fluttering of the leaf contribute jointly to the enhancement (Haseba et al., 1986). For the upstream-facing surface of a leaf model, the enhancement of the coefficient is substantially created by a pressure distribution on the surface resulting from the oblique attack of the flow to the surface and by fairly large eddies (Levy, 1952; Kestin et al., 1961; Kestin, 1966; Junkhan and Serovy, 1967; Haseba, 1975; Haseba and Ito, 1984; Haseba et al., 1986). For models at large fluttering numbers, the speed of the air flow attacking the model surface becomes so great that the pressure distribution grows and enhances the transfer considerably. The transfer for the downstream-facing surface of a model is enhanced by the movement of fluid over the surface through the edges of the model. Because the eddies resulting from the separation of the boundary-layer produce the oblique attack of the air stream on the surface, the attack intensifies the pressure distribution. More detailed interpretation of the transferenhancement for the downstream-facing surface requires closer observations of the flow in the boundary layer.

\section{Reference}

Harazono, Y. and Yabuki, K., 1979: Studies on the effects of wind speed on photosynthesis (8) Values of boundary layer resistance for the model leaf vibrating freely in a turbulent flow. J. Agr. Met., 35, 153-164.*

Haseba, T., 1975: Water-vapor transfer from fluttering leaves within a plant canopy. Field observations and laboratory experiments. $J$. Agr. Met., 31, 135-143.*

Haseba, T. and Ito, D., 1980: Dimension dependence of boundary-layer transfer coefficient of water-vapor for flat plant leaf. J. Agr. Met., 36, 89-94.

Haseba, T. and Ito, D., 1984: Effects of dimension and inclination of surface to air flow on boundary-layer transfer coefficients for flat 
leaves: Model experiments in laminar flow. J. Agr. Met., 40, 141-148.

Haseba, T., Ito, D., Ishida, H., Ohno, K. and Takahashi, C., 1986: Boundary-layer transfer coefficient for a fluttering leaf I. Model experiments on dimension dependence of transfer coefficient. J. Agr. Meto, 41, 311-319.

Junkhan, G. H. and Serovy, G. K., 1967: Effect of free-stream turbulence and pressure gradient on flat-plate boundary-layer velocity profiles and on heat transfer. J. Heat Mass Transfer, 89, 169-176.

Kestin, J., 1966: The effect of free-stream turbulence on heat transfer rates. Advances in Heat Transfer, 3, 1-32.

Kestin, J., Maeder, P. F. and Wang, H. E., 1961: Influence of turbulence on the transfer of heat from plates with and without a pressure gradient. Int. J. Heat Mass Transfer, 3, 133-154.

Levy, S., 1952: Heat transfer to constant-property laminar boundary-layer flows with power-function free-stream velocity and wall-temperature variation. J. Aeron. Sci., 19, 341-348.

Parkhurst, D. F., Duncan, P., Gates, D. M. and Kreith, F., 1968: Convection heat transfer from broad leaves of plants. J. Heat Transfer, C90, 71-96.

Parkhurst, D. F. and Pearman, G. I., 1974: Convective heat transfer from a semi-infinite flat plate to periodic flow at various angles of incidence. Agric. Meteorol., 13, 383-393.

Parlange, J. Y., Waggoner, P. E. and Heirhel, G. H., 1971: Boundary layer resistance and temperature distribution on still and flapping leaves. I. Theory and laboratory experiments. Plant Physiol., 48, 437-442.

Parlange, J. Y. and Waggoner, P. E., 1972: Boundary layer resistance and temperature distribution on still and flapping leaves. II. Field experiments. Plant Physiol., 50, 60-63.

Pearman, G. I., Weaver, H. L. and Tanner, C. B., 1972: Boundary layer heat transfer coefficients under field conditions. Agric. Meteorol., 10, 83-92.

Raschke, K., 1956: Über die physikalischen Beziehungen zwischen Wärmeübergangszahl, Strahlungsaustausch, Temperatur und Transpiration eines Blattes. Planta, 48, 200-238.

Schuepp, P. H., 1972: Studies of forced convection heat and mass transfer of fluttering realistic leaf models. Boundary-Layer Met., 2, 263-274.

Yabuki, K. and Harazono, Y., 1978: Studies on the effects of wind speed on photosynthesis. (7) The structure of boundary layer near leaf surface. J. Agr. Met., 34, 87-94.*

* written in Japanese with English summary.

\title{
風に摇れる植物葉面の境界層輸送係数 2. 主気流に対する面の傾きと振動数の効果
} 長谷場徹也・伊藤代次郎・西川 敦 (愛媛大学農学部)

\begin{abstract}
要約
風に摇れる植物葉面の境界層輸送係数と振動の中心位 置における面の主気流に対する迎角及び摇れの振動数之 の関係を，室内に打ける模型葉の蒸発実験加求めた。 人工の变動気流は主流速が周期的に変化し, 植物群落内 の風とほぼ同等の強さの乱れを持つむのにした。乙の気 流中でいろいろな寸法の長方形の平板模型葉を主気流に 対する面の迎角を変え，また振動数を変えて主流速の変 化と同期して摇らせ，水蒸気輸送係数を求めた。

輸送係数の測定值の多くは層流境界層輸送係数の理論 値より大きかった。 $3 \times 10^{3}$ ないし $3 \times 10^{4}$ の臨界 Reynolds 数以下で模型葉の輸送係数は, 主気流に対し傾いて摇れ る場合に扔いても, 平均流速の平方根に見掛け上比例し た。乙の場合, 各振動数・各迎角ごとに, 輸送係数の実 測值の理論値に対する比(輸送係数増大率)を面の寸法で 表わす実験式を求めた。輸送係数増大率は迎角が負の場 合ほど大きく，摇れの振動数が高いほど大きかった。
\end{abstract}

